University of Nebraska - Lincoln

DigitalCommons@University of Nebraska - Lincoln

1990

\title{
Carbon Dioxide Exchange in a Temperate Grassland Ecosystem
}

S. B. Verma

University of Nebraska - Lincoln

Follow this and additional works at: https://digitalcommons.unl.edu/natrespapers

Part of the Natural Resources and Conservation Commons, Natural Resources Management and Policy Commons, and the Other Environmental Sciences Commons

Verma, S. B., "Carbon Dioxide Exchange in a Temperate Grassland Ecosystem" (1990). Papers in Natural Resources. 1205.

https://digitalcommons.unl.edu/natrespapers/1205

This Article is brought to you for free and open access by the Natural Resources, School of at DigitalCommons@University of Nebraska - Lincoln. It has been accepted for inclusion in Papers in Natural Resources by an authorized administrator of DigitalCommons@University of Nebraska - Lincoln. 


\title{
CARBON DIOXIDE EXCHANGE IN A TEMPERATE GRASSLAND ECOSYSTEM ${ }^{1}$
}

\author{
JOON KIM and SHASHI B. VERMA \\ Department of Agricultural Meteorology, University of Nebraska-Lincoln, Lincoln, NE 68583-0728, \\ U.S.A.
}

(Received in final form 16 January, 1990)

\begin{abstract}
Carbon dioxide exchange was measured, using the eddy correlation technique, over a tallgrass prairie in northeastern Kansas, U.S.A., during a six-month period in 1987. The diurnal patterns of daytime and nocturnal $\mathrm{CO}_{2}$ fluxes are presented on eight selected days. These days were distributed throughout most of the growing season and covered a wide range of meteorological and soil water conditions. The midday $\mathrm{CO}_{2}$ flux reached a maximum of $1.3 \mathrm{mg} \mathrm{m}^{-2}$ (ground area) s $\mathrm{s}^{-1}$ during early July and was near zero during the dry period in late July. The dependence of the daytime carbon dioxide exchange on pertinent controlling variables, particularly photosynthetically active radiation, vapor pressure deficit and soil water content is discussed. The nocturnal $\mathrm{CO}_{2}$ flux (soil plus plant respiration) averaged $-0.4 \mathrm{mg} \mathrm{m}^{-2}$ (ground area) $\mathrm{s}^{-1}$ during early July and was about $-0.2 \mathrm{mg} \mathrm{m}^{-2} \mathrm{~s}^{-1}$ during the dry period.
\end{abstract}

\section{Introduction}

The North American grassland, which extends from Saskatchewan to Mexico and from the Rockies to the Mississippi river, may be primarily divided into the tallgrass prairie, mixed grasslands and the shortgrass prairie (Clements and Shelford, 1939). Generally, tallgrasses and forbs occupy the eastern portion and moister habitats while shorter vegetation occupies western and drier habitats (Bazzaz and Parrish, 1982).

Global atmospheric $\mathrm{CO}_{2}$ studies and models have generally lacked reliable information on $\mathrm{CO}_{2}$ exchange in various terrestrial ecosystems, including the grasslands. A number of field and laboratory studies have been conducted on the physiological and morphological adaptations of individual grass species (e.g., Risser, 1985). Very few measurements, however, exist on the carbon dioxide exchange and its seasonal variation in this ecosystem.

We employed the eddy correlation technique to measure fluxes of moisture, heat and carbon dioxide at a tallgrass prairie site near the Konza Prairie Research Natural Area in Kansas, U.S.A. during the First ISLSCP ${ }^{3}$ Field Experiment (FIFE) in 1987. Information on the surface energy budget components and canopy surface and aerodynamic conductances was reported in a previous paper (Kim and

\footnotetext{
${ }^{1}$ Published as Paper No. 9061, Journal Series, Agricultural Research Division, University of NebraskaLincoln, U.S.A.

2 Research Associate and Professor, respectively.

${ }^{3}$ ISLSCP: International Satellite Land Surface Climatology Project (for details, see Sellers et al., 1988).
} 
Verma, 1990). Here we present results on carbon dioxide exchange in this ecosystem. The objectives of this paper are to evaluate the diurnal and seasonal variations in daytime and nocturnal $\mathrm{CO}_{2}$ fluxes and to study their dependence on pertinent environmental variables.

\section{Materials and Methods}

\subsection{Site AND vegetation}

The study site (latitude $39^{\circ} 03^{\prime} \mathrm{N}$, longitude $96^{\circ} 32^{\prime} \mathrm{W}, 445 \mathrm{~m}$ above sea level) was located near Manhattan, Kansas. Soil at the site is predominantly Dwight silty clay loam (Typic Natrustolls). The soil bulk density averaged about $1.15 \mathrm{Mg} \mathrm{m}^{-3}$ for the top $0.30 \mathrm{~m}$. The prairie was burned annually in early spring. The experimental area was not grazed in 1986 and 1987.

Percent species composition at the study site was estimated using the modified step-point method (Owensby, 1973). The vegetation is composed principally of three $\mathrm{C}_{4}$ grass species: Andropogon gerardii, Sorghastrum nutans, and Panicum virgatum (Table I).

\subsection{Plant and soil measurements}

Leaf area index (LAI) was measured with an area meter (LI-COR ${ }^{4}$, Inc., Lincoln, NE, Model LI-3000). The surface soil water content $(0-0.1 \mathrm{~m})$ was monitored gravimetrically and subsurface water content $(0.1-1.4 \mathrm{~m})$ was measured with a neutron probe (Campbell Pacific Nuclear Co., Pacheco, CA, Model 503) on a weekly basis. The neutron probe was calibrated at the field site prior to the experiment.

\section{TABLE I}

Percent species composition at the experimental site (flowering stage, 1987) estimated by the modified step-point method (Owensby 1973)

\begin{tabular}{lc}
\hline Species & $\%$ \\
\hline Andropogon gerardii (Big bluestem) $\left(\mathrm{C}_{4}\right)$ & 27.1 \\
Sorghastrum nutans (Indiangrass) $\left(\mathrm{C}_{4}\right)$ & 22.2 \\
Panicum virgatum (Switchgrass) $\left(\mathrm{C}_{4}\right)$ & 16.6 \\
Sporobolus asper (Tall dropseed) $\left(\mathrm{C}_{4}\right)$ & 7.0 \\
Schizachyrium scoparium (Little bluestem) $\left(\mathrm{C}_{4}\right)$ & 4.7 \\
Bouteloua gracilis (Blue grama) $\left(\mathrm{C}_{4}\right)$ & 4.3 \\
Dichanthelium oligosanthes (Scribner panicum) $\left(\mathrm{C}_{3}\right)$ & 4.0 \\
Agropyron smithii (Western wheatgrass) $\left(\mathrm{C}_{3}\right)$ & 1.2 \\
Other grasses & 2.4 \\
Sedges & 6.3 \\
Forbs and woody plants & 4.2 \\
\hline
\end{tabular}

\footnotetext{
${ }^{4}$ Trade names and company names are included for the benefit of the reader and imply no endorsement or preferential treatment.
} 


\subsection{Micrometeorological MEASUREMENTS}

The eddy correlation instrument array included: a rapid response $\mathrm{CO}_{2}$ sensor with a $0.2 \mathrm{~m}$ path length (Bingham et al., 1978; Anderson et al., 1984), a Lyman alpha hygrometer (A.I.R. Inc., Boulder, CO, Model LA-1) with a $5 \mathrm{~mm}$ path length, and a one-dimensional sonic anemometer (Kaijo Denki Co., Tokyo, Japan, Model DAT-100), mounted on a horizontal boom at $2.25 \mathrm{~m}$ above ground. The data were low-pass filtered using 8-pole Butterworth active filters with $12.5 \mathrm{~Hz}$ cutoff frequency and were sampled at $20 \mathrm{~Hz}$. Sampling, recording, and near real-time processing of data were done with an IBM PC-AT microcomputer (details are available in previous reports e.g., Verma et al., 1986, 1989). Fluxes were obtained from covariances computed over 30-min averaging periods. Values of $\mathrm{CO}_{2}$ flux were corrected for the effects of spatial separation of sensors following Moore (1986) and the variation in air density due to simultaneous transfers of latent and sensible heat following Webb et al. (1980).

Photosynthetically active radiation (PAR) was measured with quantum sensors (LI-COR, Inc., Lincoln, NE, LI-190SB) located at $2.0 \mathrm{~m}$ above ground. Mean air temperature and humidity were measured with an aspirated ceramic wick psychrometer at $2.25 \mathrm{~m}$ above ground. Mean soil temperature $(0-0.05 \mathrm{~m})$ was measured with platinum resistance thermometers. Mean horizontal wind speed was measured with a three-cup anemometer (Cayuga Development, Ithaca, NY, Model WP-1) located at $2.25 \mathrm{~m}$ above ground.

\section{Results and Discussion}

\subsubsection{Daytime $\mathrm{CO}_{2}$ Flux}

Figure 1 shows the seasonal variations in green LAI, rainfall and soil water content. Stages in the annual life cycle of the prairie vegetation are also indicated in Figure 1. The green LAI reached its maximum of about 3.2 toward the end of June during the peak growth stage, and gradually decreased with senescence of the prairie vegetation. Precipitation was generally ample from May to September, except during three weeks in late July-early August. The volumetric water content $\left(\theta_{v}\right)$ of the top $0.3 \mathrm{~m}$ of soil was generally above $0.25 \mathrm{~m}^{3} \mathrm{~m}^{-3}$ during May through September, except for the dry period. During the dry period, $\theta_{v}$ reached as low as $0.16 \mathrm{~m}^{3} \mathrm{~m}^{-3}$ in late July and moisture stress conditions prevailed.

\subsection{Diurnal AND SEAsonal Variations}

\subsubsection{Daytime $\mathrm{CO}_{2}$ Flux}

The diurnal patterns of the atmospheric $\mathrm{CO}_{2}$ flux ${ }^{5}(\mathrm{Fc})$ and the incoming photosynthetically active radiation ${ }^{6}$ (PAR) for eight selected days are presented in Figures

${ }_{5}^{5}$ The sign convention employed here is such that the $\mathrm{CO}_{2}$ flux directed toward the surface is positive. $\mathrm{CO}_{2}$ fluxes are reported on a per ground area basis.

${ }^{6}$ The conversion factor of photon units $\left(\mu E i \mathrm{~m}^{-2} \mathrm{~s}^{-1}\right)$ to radiometric units $\left(\mathrm{W} \mathrm{m}^{-2}\right)$ is approximately: $4.6 \mu E i \mathrm{~m}^{-2} \mathrm{~s}^{-1} \approx 1 \mathrm{~W} \mathrm{~m}^{-2}$. 

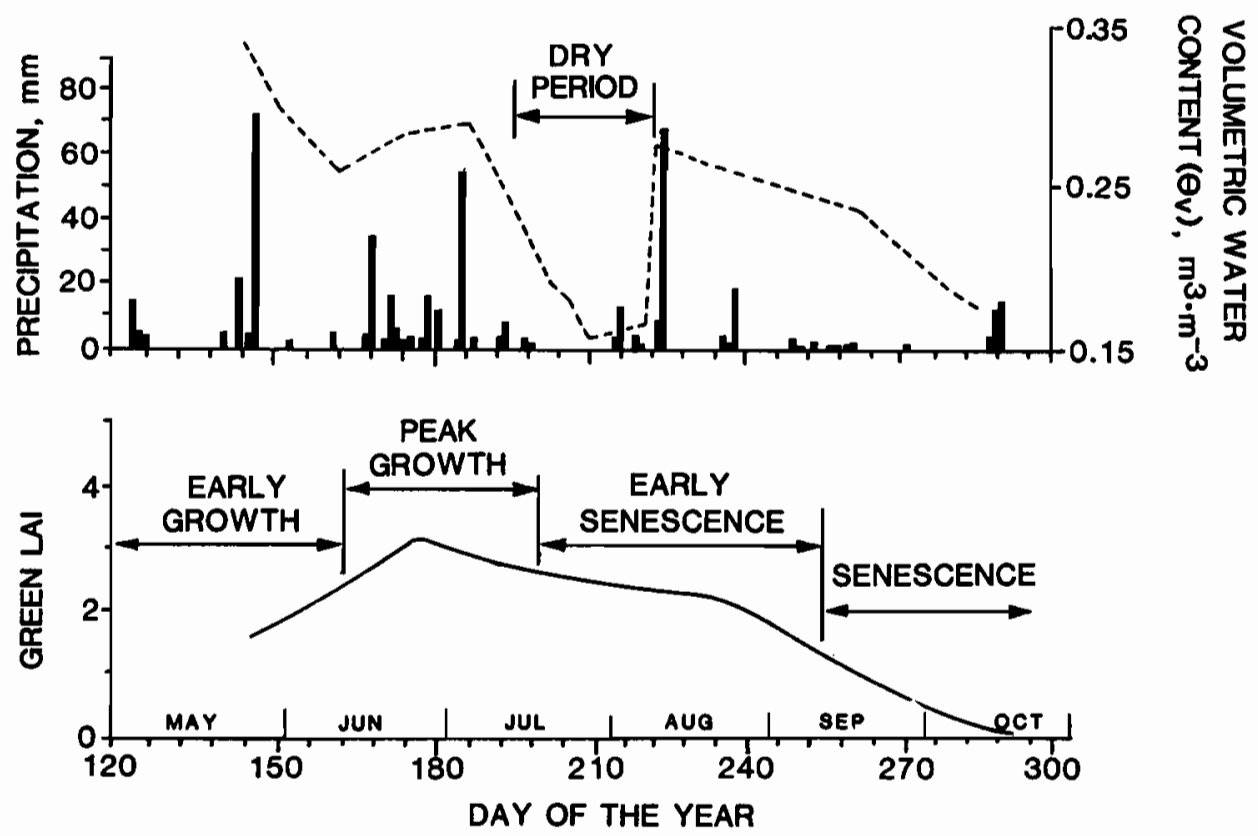

Fig. 1. Seasonal variations in green leaf area index, precipitation, and volumetric soil water content $(0-0.3 \mathrm{~m}$ depth $)$.

\section{TABLE II}

Midday (averaged during 1230-1430 hr, Central standard time) values of mean air temperature $(T)$, vapor pressure deficit $(D)$, wind speed $(U)$ on selected days in 1987. These variables were measured at a height of $2.25 \mathrm{~m}$ above the ground. The values of the volumeteric soil water content $(0-0.3 \mathrm{~m}$ depth) $\left(\theta_{v}\right)$ and the green leaf area index (LAI) are also included

\begin{tabular}{lllllll}
\hline Date & $\begin{array}{l}\text { Annual life } \\
\text { cycle stage }\end{array}$ & $T$ & $D$ & $U$ & $\theta_{v}$ & LAI \\
\cline { 3 - 7 } & & ${ }^{\circ} \mathrm{C}$ & $\mathrm{kPa}$ & $\mathrm{m} \mathrm{s}^{-1}$ & $\mathrm{~m}^{3-3}$ & \\
\hline 5 June & $\begin{array}{l}\text { Early } \\
\text { Growth }\end{array}$ & 271 & 189 & 40 & 028 & 19 \\
& Peak & & & & & \\
2 July & Growth & & 1.25 & 3.3 & 0.34 & 3.0 \\
& Early & 33.3 & 2.82 & 5.9 & 0.19 & 2.7 \\
23 July* & Senescence & 37.1 & 4.30 & 5.5 & 0.16 & 2.6 \\
30 July* & & 29.9 & 2.42 & 2.9 & 0.19 & 2.5 \\
10 August* & & 33.7 & 2.33 & 5.6 & 0.34 & 2.4 \\
15 August & Senescence & 20.0 & 1.70 & 7.8 & 0.13 & 0.3 \\
4 September & 8 October & & & & & \\
\hline
\end{tabular}

* Day from the dry period (see Figure 1). 
2a-h. Meteorological and soil water conditions and LAI are summarized in Table II. On 5 June (early growth), the green LAI was 1.9 and $\theta_{v}$ was $0.28 \mathrm{~m}^{3} \mathrm{~m}^{-3}$. In response to increasing $\mathrm{PAR}, F_{c}$ increased rapidly after sunrise until about noon and then decreased with diminishing radiation load later in the day (Figure 2a). Peak $F_{c}$ of $1.1 \mathrm{mg} \mathrm{m}^{-2}$ (ground area) $\mathrm{s}^{-1}$ occurred at noon, whereas PAR reached its peak of $2060 \mu E i \mathrm{~m}^{-2} \mathrm{~s}^{-1}$ at $1330 \mathrm{hr}$.

It was partly cloudy on 2 July (peak growth) in the morning and became clear in the afternoon. The diurnal pattern of $F_{c}$ followed that of PAR quite closely (Figure 2b). Both $F_{c}$ and PAR reached their peaks at about $1300 \mathrm{hr}$ with values of $1.3 \mathrm{mg} \mathrm{m}^{-2} \mathrm{~s}^{-1}$ and $2084 \mu E i \mathrm{~m}^{-2} \mathrm{~s}^{-1}$, respectively. Greater leaf area $(\mathrm{LAI} \approx 3.0)$ and ample soil water $\left(\theta_{v}=0.34 \mathrm{~m}^{3} \mathrm{~m}^{-3}\right)$ on this day resulted in somewhat greater $\mathrm{CO}_{2}$ exchange as compared to that on 5 June. As will be discussed later, the small vapor pressure deficit on 2 July (see Table II) may have also contributed to this result.

With the onset of the dry period toward the end of the peak growth stage (late July), the magnitudes and patterns of $F_{c}$ changed. Soil moisture decreased significantly (Figure 1) and $\theta_{v}$ on 23 July was about $0.19 \mathrm{~m}^{3} \mathrm{~m}^{-3}$. On this day, the vapor pressure deficit $(D)$ increased rapidly in the morning and reached up to $3.2 \mathrm{kPa}$ in the afternoon. Midday air temperature $(T)$ was around $33^{\circ} \mathrm{C}$. The $\mathrm{CO}_{2}$ flux reached its peak $\left(0.6 \mathrm{mg} \mathrm{m}^{-2} \mathrm{~s}^{-1}\right)$ at $1000 \mathrm{hr}$ and then decreased thereafter even though PAR continued to increase until the midday hours (Figure 2c). The value of $F_{c}$ was around $0.2 \mathrm{mg} \mathrm{m}^{-2} \mathrm{~s}^{-1}$ during most of the afternoon.

As the dry period progressed, the peak $F_{c}$ shifted further toward the morning hours. On 30 July the soil water availability was low $\left(\theta_{v}=0.16 \mathrm{~m}^{3} \mathrm{~m}^{-3}\right)$, and the atmospheric evaporative demand was very high (Table $\mathrm{II}$ ). The $\mathrm{CO}_{2}$ flux was suppressed drastically and the maximum $F_{c}$ of $0.2 \mathrm{mg} \mathrm{m}^{-2} \mathrm{~s}^{-1}$ occurred at $0900 \mathrm{hr}$ (Figure 2d). The $\mathrm{CO}_{2}$ flux in the afternoon averaged about $-0.1 \mathrm{mg} \mathrm{m}^{-2} \mathrm{~s}^{-1}$ (directed away from the vegetation).

The soil moisture conditions improved in early August due to frequent rainfall. On 10 August (Figure $2 e$ ) $F_{c}$ was directed back toward the vegetation during the day with a peak of $0.6 \mathrm{mg} \mathrm{m}^{-2} \mathrm{~s}^{-1}$ occurring in late morning. With $67 \mathrm{~mm}$ of rainfall on 13 August (Figure 1) the soil water condition improved further. On 15 August the peak $F_{c}\left(0.5 \mathrm{mg} \mathrm{m}^{-2} \mathrm{~s}^{-1}\right)$ shifted toward noon (Figure $2 \mathrm{f}$ ) and the diurnal pattern of $F_{c}$ generally followed that of PAR.

Midday $F_{c}$ on 4 September (Figure $2 \mathrm{~g}$ ) was $0.6 \mathrm{mg} \mathrm{m}^{-2} \mathrm{~s}^{-1}$, about $50 \%$ of the early season rates observed during the peak growth stage. The peak $F_{c}$ shifted back toward the midday hours and the diurnal pattern of $F_{c}$ followed that of PAR quite closely. The photosynthetic rates diminished as the prairie vegetation senesced (Figure $2 \mathrm{~h}$ ). On 8 October (senescence stage), the value of $F_{c}$ was less than $0.1 \mathrm{mg} \mathrm{m}^{-2} \mathrm{~s}^{-1}$ during the day.

These diurnal and seasonal patterns of $F_{c}$ are similar to the results reported by Ripley and Saugier (1974) from their study of a shortgrass prairie in Saskatchewan, Canada. They found that $F_{c}$ reached a peak of $0.3-0.4 \mathrm{mg} \mathrm{m}^{-2}$ (ground area) s 

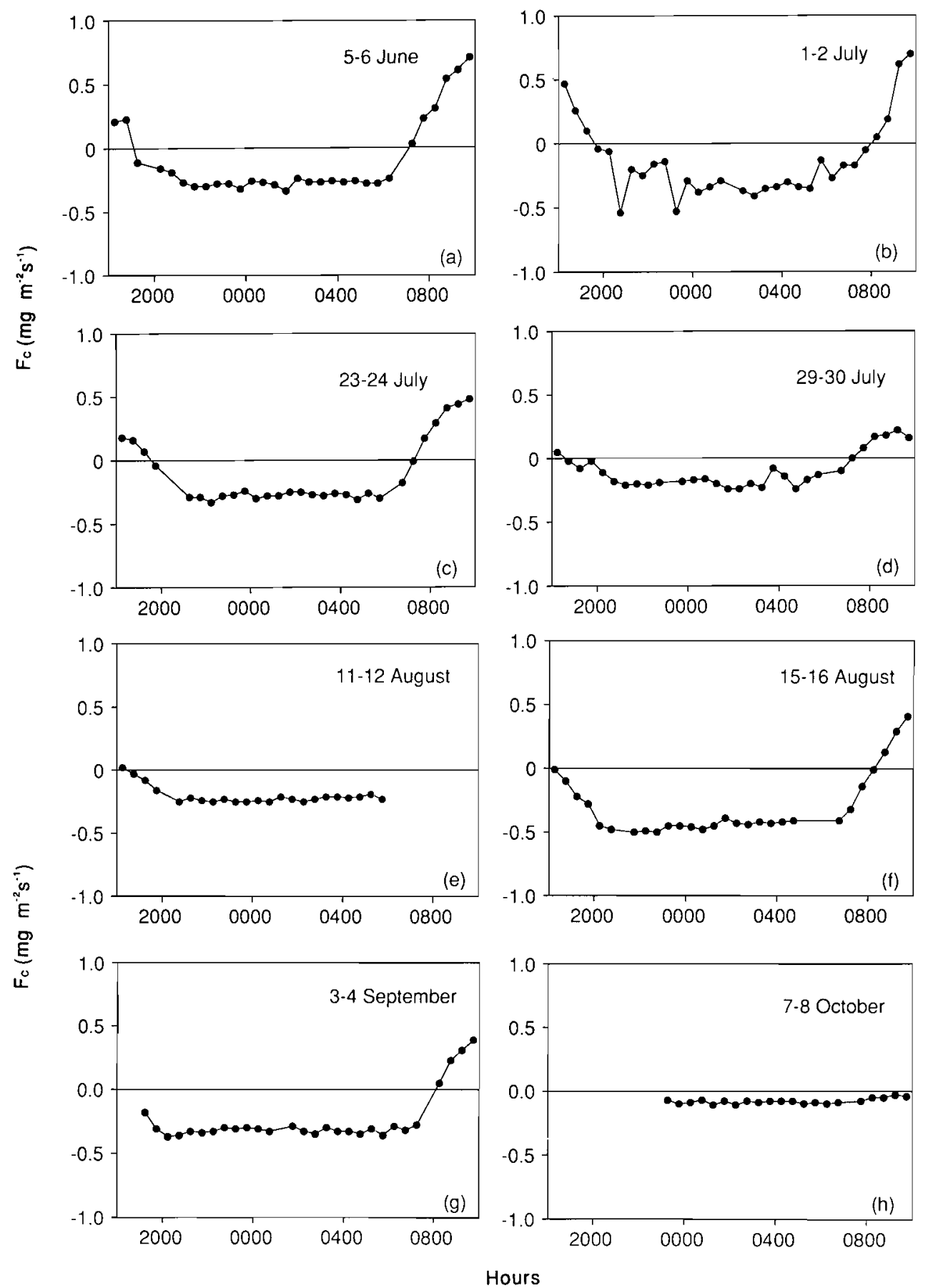

Fig. 3. Nocturnal $\mathrm{CO}_{2}$ flux on 8 selected nights. Central standard time is shown. 
TABLE III

Nocturnal (averaged during 2200-0600 hr, Central standard time) values of mean air temperature $(T)$ and wind speed $(U)$ on selected days in 1987. The values of the volumetric soil water content and the green leaf area index are given in Table II

\begin{tabular}{|c|c|c|c|}
\hline \multirow[t]{2}{*}{ Date } & \multirow{2}{*}{$\begin{array}{l}\text { Annual life } \\
\text { Cycle stage }\end{array}$} & \multirow{2}{*}{$\frac{T}{{ }^{\circ} \mathrm{C}}$} & $U$ \\
\hline & & & $\mathrm{m} \mathrm{s}^{-1}$ \\
\hline 5-6 June & $\begin{array}{l}\text { Early } \\
\text { Growth }\end{array}$ & 16.9 & 3.8 \\
\hline 1-2 July & $\begin{array}{l}\text { Peak } \\
\text { Growth }\end{array}$ & 18.4 & 2.0 \\
\hline 23-24 July* & Early & 24.7 & 3.9 \\
\hline 29-30 July* & Senescence & 26.3 & 3.8 \\
\hline 11-12 August* & & 24.9 & 3.7 \\
\hline 15-16 August & & 27.9 & 6.9 \\
\hline 3-4 September & & 21.8 & 3.8 \\
\hline 7-8 October & Senescence & 6.5 & 3.8 \\
\hline
\end{tabular}

*Day from the dry period (see Figure 1).

in early July and decreased with increasing plant water stress and senescence later in the season. Their values were lower than the values for the tallgrass prairie studied here, primarily because of a smaller leaf area $(\mathrm{LAI} \approx 1.0)$ and the dominance of $\mathrm{C}_{3}$ grasses in their study.

\subsubsection{Nocturnal $\mathrm{CO}_{2}$ Flux (Soil plus Plant Respiration)}

The $\mathrm{CO}_{2}$ flux $\left(F_{c}\right)$ measured on eight selected nights are presented in Figures 3ah. Meteorological conditions are summarized in Table III. Generally, $F_{c}$ decreased rapidly between 1900 and $2000 \mathrm{hr}$. Values of $F_{c}$ were relatively stable between about $2200 \mathrm{hr}$ and about an hour before sunrise. Excluding the transition periods near sunrise and sunset, the respiration (plant and soil) rates during the early growth (Figure $3 \mathrm{a}$ ) and peak growth stages (Figure $3 \mathrm{~b}$ ) ranged from -0.3 to $-0.5 \mathrm{mg} \mathrm{m}^{-2}$ (ground area) $\mathrm{s}^{-1}$.

During the dry period, the extreme weather conditions and low availability of soil water (Table II) affected plant growth and reduced the rate of respiration from the plants and soil. The respiration rate during this period averaged about $-0.2 \mathrm{mg} \mathrm{m}^{-2} \mathrm{~s}^{-1}$ (Figures $3 \mathrm{c}-\mathrm{e}$ ). In response to improved soil moisture conditions during mid August and early September, the respiration rate increased and ranged from -0.3 to $-0.5 \mathrm{mg} \mathrm{m}^{-2} \mathrm{~s}^{-1}$ (Figures $3 \mathrm{f}$ and $\mathrm{g}$ ). The increase in the respiration rate was due to the enhanced photosynthetic activity after the rain and to the increased activity of soil microorganisms. The respiration rate diminished as the season progressed. During the senescence stage (Figure 3h), the respiration rate averaged about $-0.1 \mathrm{mg} \mathrm{m}^{-2} \mathrm{~s}^{-1}$.

These patterns of nocturnal $F_{c}$ are similar to those reported by Ripley and 
Saugier (1974). The magnitudes in their shortgrass prairie were smaller $\left(0.1-0.2 \mathrm{mg} \mathrm{m}^{-2} \mathrm{~s}^{-1}\right.$ in early July), however.

\subsection{Factors controlling daytime $\mathrm{CO}_{2}$ FLUX}

\subsubsection{Photosynthetically Active Radiation}

Figure 4 shows the relationship between $F_{c}$ and PAR for different stages in the annual life cycle of the prairie vegetation. Data were selected when the soil water condition was favorable $\left[\theta_{v}(0-0.3 \mathrm{~m}\right.$ depth $\left.)>0.25 \mathrm{~m}^{3} \mathrm{~m}^{-3}\right]$ and when the vapor pressure deficit $(D)$ was low $(0-1.5 \mathrm{kPa})$. As expected, a hyperbolic relationship existed between $F_{c}$ and PAR during the early growth, peak growth and early senescence stages. Data in Figure 4 were fitted with a rectangular hyperbola (commonly used in physiological studies; see e.g. Landsberg, 1977) of the form:

$$
F_{c}=\frac{\left(F_{c m}\right)(b)\left(\mathrm{PAR}-\mathrm{PAR}^{*}\right)}{F_{c m}+(b)\left(\mathrm{PAR}-\mathrm{PAR}^{*}\right)}
$$

where $F_{c m}$ is the maximum $F_{c}, \mathrm{PAR}^{*}$ is the value of PAR at the light compensation
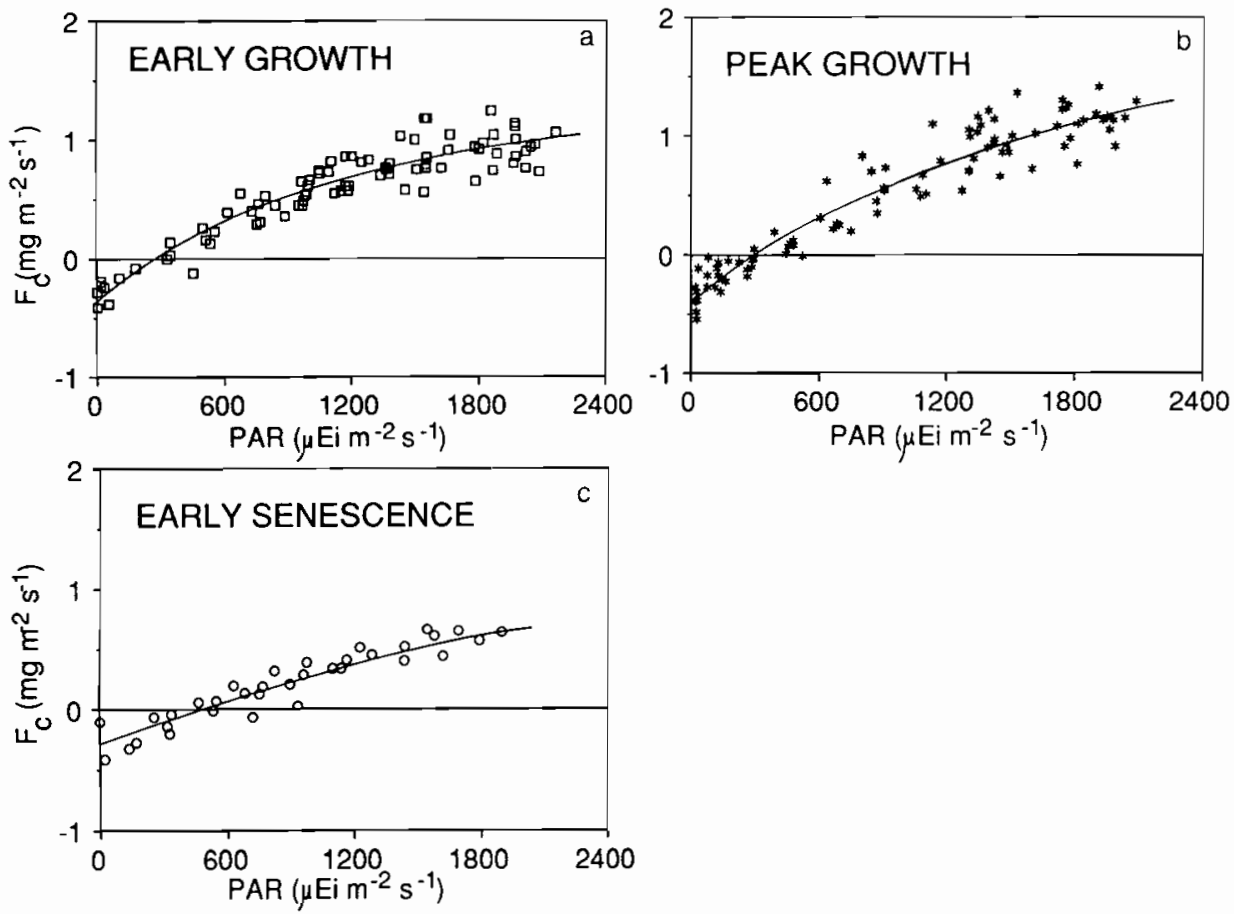

Fig. 4. Daytime $\mathrm{CO}_{2}$ flux as a function of photosynthetically active radiation (PAR) at different annual life cycle stages of the prairie vegetation. Data were fitted with a rectangular hyperbola, $F_{c}=$ $F_{c m} b \quad\left(\mathrm{PAR} \mathrm{PAR}^{*}\right) /\left[F_{c m}+b \quad\left(\mathrm{PAR} \mathrm{PAR}^{*}\right)\right]$. Data were selected when $\boldsymbol{\theta}_{\mathrm{v}}>0.25 \mathrm{~m}^{3} \mathrm{~m}^{-3}$ and $0.0<\mathrm{D}<1.5 \mathrm{kPa}$. 

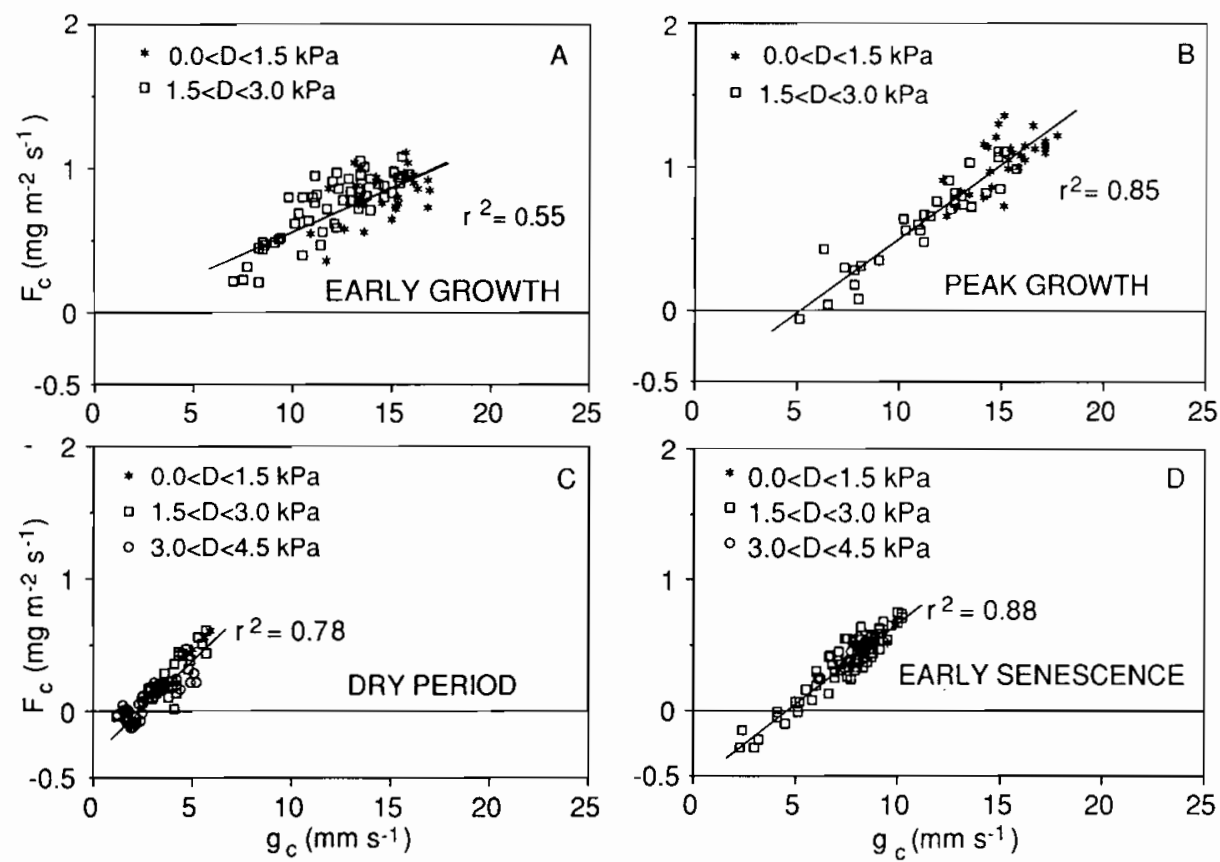

Fig. 6. Relationship between the daytime $\mathrm{CO}_{2}$ flux $\left(F_{c}\right)$ and the canopy surface conductance $\left(g_{c}\right)$. Linear regression lines are included.

and vapor pressure deficit, using the Penman-Monteith equation (see Kim and Verma, 1990, for details). Figures 6a-d show the relationship between $F_{c}$ and $g_{c}$. The data are grouped in three intervals of $D$. Data on rainy days and days after rain were excluded; and to minimize the confounding effect of dew on leaves, data before $1000 \mathrm{hr}$ were excluded.

Although there is some scatter in the data, the relationship between $F_{c}$ and $g_{c}$ appears to be linear throughout the season (Figures 6a-d) (this relationship does not appear to have been affected by the values of $D$, although low $g_{c}$ values were usually associated with large values of $D$ ). Similar $F_{c}-g_{c}$ relationships have been reported in previous studies on individual leaves. For example, Knapp (1985) reported parallel changes between net photosynthesis and leaf conductance of Andropogon gerardii and Panicum virgatum in a tallgrass prairie.

It should be noted that parallel changes shown in Figures 6a-d do not necessarily suggest cause and effect relationships between $F_{c}$ and $g_{c}$. However, these results further substantiate the physiological significance of $g_{c}$, as has been pointed out earlier.

\subsection{Factors controlling nocturnal $\mathrm{CO}_{2}$ FluX}

Temperature and soil water availability are the primary environmental factors that control the nocturnal $\mathrm{CO}_{2}$ emanating from the soil and from the plant (Kucera 


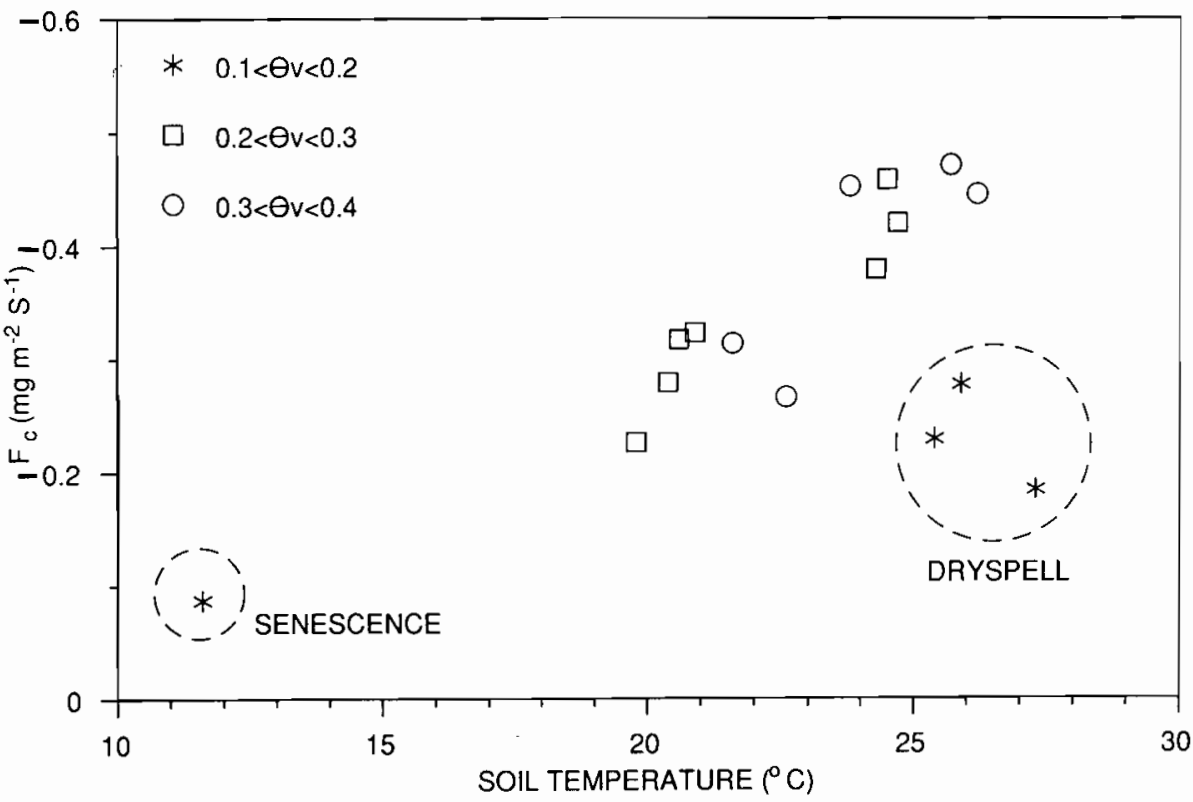

Fig. 7. The nocturnal $\mathrm{CO}_{2}$ flux $\left(F_{c}\right)$ as a function of soil temperature.

and Kirkham, 1971; Redmann, 1978). The response of the nocturnal $\mathrm{CO}_{2}$ exchange to soil temperature ( $T$ measured at $0-0.05 \mathrm{~m}$ depth) is given in Figure 7 (data were averaged from 2200 to $0600 \mathrm{hr}$ to minimize the confounding effect during the transition periods near sunrise and sunset). The data are grouped in three different intervals of soil moisture content $\left(\theta_{\nu}\right)$. Except for the period of low soil moisture $\left(0.1<\theta_{v}<0.2 \mathrm{~m}^{3} \mathrm{~m}^{-3}\right.$; see encircled data in Figure 7), the magnitude of

\section{TABLE IV}

Multiple regression analysis of the relationship of nocturnal $\mathrm{CO}_{2}$ flux $\left(F_{c}\right)$ to soil temperature $\left(T_{\text {soil }}\right)$ soil moisture $\left(\theta_{v}\right)$ and wind speed $(U)$. All coefficients of determination $\left(r^{2}\right)$ were statistically significant $(0.01$ level)

\begin{tabular}{ll}
\hline Variables & Coefficient of determination $\left(r^{2}\right)$ \\
\hline Dependent & \\
Nocturnal $\mathrm{CO}_{2}$ flux & \\
& \\
Independent & \\
$T_{\text {soil }}$ & 0.31 \\
$\theta_{\nu}$ & 0.56 \\
$U$ & 0.35 \\
$T_{\text {soil }}, \theta_{\nu}$ & 0.71 \\
$T_{\text {soil }}, \theta_{\nu}, U$ & 0.91 \\
\hline
\end{tabular}


nocturnal $F_{c}$ appeared to increase with increasing $T_{\text {soil }}$. A linear regression through the data (nocturnal $F_{c}$ and $T_{\text {soil }}$ ), however, yielded a coefficient of determination $\left(r^{2}\right)$ of only 0.31 (Table IV). The soil moisture availability $\left(\theta_{v}\right)$ accounted for $56 \%$ of the variability in the nocturnal $\mathrm{CO}_{2}$ exchange. The inclusion of $\theta_{v}$ with $T_{\text {soil }}$ increased the $r^{2}$ value to 0.71 .

The dependence of the nocturnal $\mathrm{CO}_{2}$ exchange on wind speed $(U)$ was also examined. A regression with wind speed alone yielded $r^{2}$ of 0.35 , a small but significant value. A multiple regression, computed with $T_{\text {soil }}, \theta_{v}$ and $U$ as independent variables, accounted for about $91 \%$ of the variation in nocturnal $\mathrm{CO}_{2}$ fluxes (Table IV).

\section{Summary and Conclusions}

Results are reported on the carbon dioxide exchange measured in a temperate grassland ecosystem near Manhattan, Kansas during the growing season of 1987 .

During the most vigorous stage of plant growth (June-July), the midday $\mathrm{CO}_{2}$ flux $\left(F_{c}\right)$ reached a seasonal peak of $1.3 \mathrm{mg} \mathrm{m}^{-2}$ (ground area) $\mathrm{s}^{-1}$ and the nocturnal $F_{c}$ (soil + plant respiration) averaged about $-0.4 \mathrm{mg} \mathrm{m}^{-2} \mathrm{~s}^{-1}$.

The dry period encountered during late July-early August, a rather typical feature of the climate of this region, caused $F_{c}$ to decline to almost zero during the day. Nocturnal $F_{c}$ averaged about $-0.2 \mathrm{mg} \mathrm{m}^{-2} \mathrm{~s}^{-1}$ during this dry period.

With frequent rainfall in mid-August to early September, the daytime $F_{c}$ recovered to about $30-50 \%$ of the early season rates whereas the nocturnal $F_{c}$ recovered almost fully. In October, plant senescence, low temperature and low soil water availability reduced the midday $F_{c}$ to less than $0.1 \mathrm{mg} \mathrm{m}^{-2} \mathrm{~s}^{-1}$, while the nocturnal $F_{c}$ was around $-0.1 \mathrm{mg} \mathrm{m}^{-2} \mathrm{~s}^{-1}$.

Under nonlimiting soil moisture conditions, the major determinant of the daytime $\mathrm{CO}_{2}$ flux was photosynthetically active radiation. Examination of our data under both nonlimiting and limiting soil moisture conditions indicated that the $\mathrm{CO}_{2}$ flux was suppressed significantly by high vapor pressure deficit. The daytime $F_{c}$ and the canopy surface conductance were strongly correlated over a wide range of environmental conditions throughout the season. The nocturnal $F_{c}$ seemed to be dependent primarily on soil moisture availability and also on soil temperature and wind speed.

\section{Acknowledgements}

This study was supported by the National Aeronautics and Space Administration under Grant NAG5-890 and by the National Science Foundation under Grant ATM-8519026. Messrs. H. D. Earl and Sheldon Sharp provided valued assistance in maintenance of instruments and data acquisition systems. Mr. James Hines assisted in data computation. We wish to express our sincere appreciation to $\mathrm{Mr}$. Robert Clement for his valuable help in data collection and processing, and to 
Mr. Randall Kennedy and Dr. Joseph Shinn of the Lawrence Livermore National Laboratory for their help in proper maintenance of the rapidresponse $\mathrm{CO}_{2}$ sensor. We thank Dr. James Stubbendieck for his help in estimating species composition; Mrs. Sharon Kelly for the stenographic work; and Drs. John M. Norman, James Stubbendieck and Charles Y. Sullivan for their review of this manuscript.

\section{References}

Anderson, D. E., Verma, S. B., and Rosenberg, N. J.: 1984, 'Eddy Correlation Measurements of $\mathrm{CO}_{2}$, Latent Heat and Sensible Heat Fluxes Over a Crop Surface', Boundary-Layer MeteoroL. 29, 263-272.

Bazzaz, F. A. and Parrish, J. A. D.: 1982, 'Organization of Grassland Communities', in J. R. Estes, R. J. Tyre, and J. N. Brunken (eds.), Grasses and Grassland, University of Oklahoma, Norman, pp. 234-254.

Bingham, G. E., Gillespie, C. H., and McQuaid, J. H.: 1978, 'Development of a Miniature, Rapid Response $\mathrm{CO}_{2}$ Sensor', Report UCRL52440, Lawrence Livermore National Laboratóry.

Clements, F. E. and Shelford, V. E.: 1939, Bioecology, John Wiley, New York.

Kim, J. and Verma, S. B.: 1990, 'Components of Surface Energy Balance in a Temperate Grassland Ecosystem', Boundary-Layer Meteorol. 51, 401-417.

Knapp, A. K.: 1985, 'Effect of Fire and Drought on the Ecophysiology of Andropogon gerardii and Panicum virgatum in a Tallgrass Prairie', Ecology 66, 1309-1320.

Kucera, C. L. and Kirkham, D. R.: 1971, 'Soil Respiration Studies in Tallgrass Prairie in Missouri', Ecology 52, 912-915.

Landsberg, J. J.: 1977, 'Some Useful Equations for Biological Studies', Expl. Agric. 13, $273-288$.

Monteith, J. L.: 1965, 'Evaporation and Environment', in G. E. Fogg (ed.), The State and Movement of Water in Living Organisms, Academic Press, New York. pp. 205-234.

Monteith, J. L.: 1981, 'Evaporation and Surface Temperature', Quart. J. Royal Meteorol. Soc. 107, $1-27$.

Moore, C. J.: 1986, 'Frequency Response Corrections for Eddy Correlation Systems', Boundary-Layer Meteorol. 37, 17-35.

Owensby, C. E.: 1973: 'Modified Step-Point System for Botanical Composition and Basal Cover Estimates', J. Range Management 26, 302-303.

Redmann, R. E.: 1978, 'Seasonal Dynamics of Carbon Dioxide Exchange in a Mixed Grassland Ecosystem', Canadian J. Botany 56, 1999-2005.

Ripley, E. A. and Saugier, B.: 1974, 'Energy and Mass Exchange of a Native Grassland in Saskatchewan,' Proceedings of the 1974 International Seminar on Heat and Mass Transfer in the Environment of Vegetation, Dubrovnik, pp. 311-325.

Risser, P. G.: 1985, 'Grassland', in B. F. Chabot and H. A. Mooney (eds.), Physiological Ecology and North American Plant Communities, Chapman and Hall, New York, pp. 232-256.

Sellers, P. J., Hall, F. G., Asrar, G., Strebel, D. E. and Murphy, R. E.: 1988, 'The First ISLSCP Field Experiment (FIFE)', Bull. Amer. Meteorol. Soc. 69, 22-27.

Shuttleworth, W. J.: 1976, 'A One-Dimensional Theoretical Description of the Vegetation-Atmosphere Interaction,' Boundary-Layer Meteorol. 10, 273-302.

Thom, A. S.: 1975, 'Momentum, Mass, and Heat Exchange of Plant Communities,' in J. L. Monteith (ed.), Vegetation and the Atmosphere. Vol. 1, Academic Press, New York, pp.57-109.

Verma, S. B., Baldocchi, D. D., Anderson, D. E., Matt, D. R., and Clement, R. J.: 1986, 'Eddy Fluxes of $\mathrm{CO}_{2}$, Water Vapor and Sensible Heat Over a Deciduous Forest,' Boundary-Layer Meteorol. 36, 71-91.

Verma, S. B., Kim, J., and Clement, R. J.: 1989, 'Carbon Dioxide, Water Vapor and Sensible Heat Fluxes Over a Tallgrass Prairie,' Boundary-Layer Meteorol. 46, 53-67.

Webb, E. K., Pearman, G. I., and Leuning, R.: 1980, 'Correction of Flux Measurements for Density Effects Due to Heat and Water Vapor Transfer,' Quart. J. Royal Meteorol. Soc. 106, 85-100. 
$\left.\right|_{1} ^{1}$ 